\title{
LINGUISTIC AND COMMUNICATIVE PECULIARITIES OF GRATITUDE EXPRESSIONS OF ENGLISH DISCOURSE
}

\author{
A. Prykhodko, Student \\ Sumy State University, \\ 2, Rymskogo-Korsakova St., Sumy, 40007, Ukraine \\ E-mail: Prykhodko56Annet@gmail.com
}

The work is executed under the direction of S. Baranova, $\mathrm{PhD}$ in Philology, Associate Professor, Sumy State University

The article deals with the multifaceted phenomenon that is gratitude, which has distinctive features in every language culture, in particular, in English. It also distinguishes the peculiarities of expressing gratitude in the context of English literary discourse. The article focuses on the linguistic and communicative peculiarities of gratitude verbalized on the pages of English literary works. It involves analyzing the circumstances of expressing gratitude, lexical means of gratitude nomination and factors, that influence the way of its verbalization. It describes a detailed analysis of common communicative situations when it is accepted to express gratitude. The article points out the cultural aspects of expressing gratitude. Special attention is paid to the pragmatic aspects of using gratitude, in particular, the distinction between the expression of compliment and gratitude for it and a gratitude-compliment.

Keywords: gratitude, literary discourse, communicative situation, pragmatic aspects https://doi.org/10.21272/Ftrk.2018.10(3)-03

Introduction. Communication is considered to be one of the most important activities of human life. Compliance with the standards of polite behavior is a guarantee of an equable, successful and non-conflict process of communication. It is known, that in the context of human communication, a special role is given to phrases expressing conventional rules of human behavior in society and belonging to social etiquette.

An important element of social etiquette is expressions of gratitude. The increasing interest towards it points out the importance of this issue in human relationships in general and in intercultural communication in particular.

«Oxford English Dictionary» [1] explains «gratitude» as the quality of being thankful; readiness to show appreciation for and to return kindness; feeling or showing an appreciation for something done or received; received or experienced with gratitude; welcome. It arises on the basis of emotional and rational assessment of what is happening; the ways of its expression are highly ritualized. Besides, gratitude can be addressed not only to specific individuals, but also to groups of people (for example, ancestors) and nonpersonalized notions: the world, God [2].

The relevance of the study is conditioned by the special interest of linguists in the study of the cultural aspects of the concept of gratitude and their manifestation in language and speech and certain impact on them. Better understanding of communicative situations in which it is accepted to express gratitude by foreign society, lexical means which are appropriate in a particular case, explicit and implicit context of thankfulness may be helpful in the process of communication with speakers whose native language is English.

The objective of the article is to analyze the main linguistic and communicative, pragmatic aspects of the English expressions of gratitude within English literary discourse.

The objective implies the following tasks of the research:

1) to define the concept "discourse" and its main types;

2) to find out the concept «gratitude» in the minds of the inhabitants of the Englishspeaking areas and generalize its classification;

3) to generalize the stereotyped means of gratitude nomination;

(C) A. Prykhodko, 2018 
4) to analyze communicative fragments expressing thankfulness and the establishment of their pragmatic aspects.

The subject matter is the expressions of gratitude in English literary discourse.

The specific topic of the study is linguistic and pragmatic aspects of expressing gratitude within English literary discourse.

The methodological basis of the study involves the communicative analysis of English expressions of thankfulness taken from the literary works of classical and contemporary American, British and Australian writers; as well as the use of the method of comparison.

Results of the research. The category of gratitude serves as a system-forming core that regulates the behavior of representatives of various linguistic cultures. However, it should be mentioned, that communicative behavior having national and cultural features is conditioned by the fact, that the concept «politeness» has different content [3, p. 90], different implicit meaning in the communicative consciousness of representatives of different cultures.

The system of intentions (illocution) of expressing gratitude includes the following components: 1) the intention to follow etiquette norms; 2) to express emotional state of the speaker; 3) to influence the behavior and the emotional state of the recipient; 4) to assess situation rationally and 5) not to be a «debtor». It should be noted, that these intentions may overlap in real communication and differently relate to the main intentions of expressing the emotional state of the subject of gratitude [4, p. 15-16].

The mental «script» of gratitude expression includes the following types of interrelated information:

1) background knowledge that any good deed must be rewarded in one way or another, that is especially important for the ritual (stereotyped) gratitude;

2) understanding of the main intentions of the subject of gratitude;

3) awareness of the fact that a potential subject of gratitude is given a particular kind of service;

4) awareness of the communicative conditions of the gratitude situation (the social roles of the communicants, the factor of the past, etc.);

5) understanding of how to express verbally the language act of gratitude (knowledge of all possible ways of expressing a sense of gratitude (direct and indirect);

6) knowledge that ingratitude is strictly condemned by society.

Therefore, the expression of gratitude is conditioned by observance of ethical rules commonly accepted in the society and it is a marker of individual's politeness and courtesy.

Language means of expressing gratitude is a field in the center of which is a metadictionary (term M. Ya. Hlovinsky) consisting of word markers such as: thank you, thankful, grateful; phrases and clichés: I'm grateful / obliged / indebted to you for ...; Much obliged to you for the favor; I can never thank you enough; I would like to express my gratitude; idioms: thank your lucky stars; I owe you (one) and so on. Phraseological or lexical units may be used to show appreciation as well: My most heartfelt thanks to you for ...; deeply indebted.

Emotionally expressive expressions of gratitude can be as follows: I do not know how to thank you; My thanks can't be expressed in words / Words cannot tell you how grateful I am / feel. Neutral forms of gratitude and response to it include: thank you, thanks, you're welcome, that's all right, that's ok, no problem, not at all, do not mention it. Phrases that are quite common in everyday conversations are the following: It was no trouble at all / anything!; It was no bother / It was a pleasure; It was a real pleasure for me to do this; My pleasure.

Expressions of gratitude are usually implemented in dialogical speech. Expressions of thankfulness for received help, encouraging, affection, etc. are the expressions of etiquette manner, courtesy and good breeding. According to the basics of etiquette a person is thankful not only in the case someone does him/her a favour, but also in a bunch of other situations.

«Філологічні трактати», Том 10, № 3 ' 2018 
It is obvious, that in English literary discourse, as, for example, in Ukrainian, a person will thank for the material benefits provided to him/her. Let's look at the example given below:

I tugged a fold of hundred-rupee notes from my pocket, and gave it to him. Scorpio took it in a faltering hand, but then slipped it into a pocket concealed inside his shirt. "Thanks, Lin,» he said, looking up quickly to meet my eyes [5, p. 38].

In this fragment, one may observe, that Scorpio, having received money in debt, doesn't seem very eloquent. Perhaps the reason for it is hidden in social and cultural factors (the dialogue is between the Australian and the Indian), the personal relationship between Scorpio and Lin, or a small amount borrowed. However, quite often, the American emphasizes the impossibility of expressing with words all the depth of the gratitude in such situations: "I do not know how to thank you», "I can not tell you how much I appreciate this», "I can not thank you enough», «I can not tell you what this means to me» [4, p. 68].

One can find expressions of appreciation for help or received service of an interlocutor addressed to the other one in literary works quite often. For e.g.:

"Thank you both very much. You've been very helpful," he said, his mind going back to the appearance of the suite [5, p. 283].

"Thank you for coming, Landon», she said. "I know you're busy, but I appreciate your taking the time to do this 》 [6, p. 20].

Well-bred person thanks for support, advice or forewarning:

"And remember this,» she instructed Meredith in the rising tones of one who is about to impart a very satisfying thought, "every dog has its day!» Meredith didn't know whether to laugh or cry. "Thank you, Mrs. Ellis», she said, "that is very encouraging» [7, p. 7].

"I can, if you can», he said, a half-worried smile confusing his face. "Whatever you do, I am with you». "Thanks, brother», I said, "sharing a hug that pressed his curly hair into my face» [5, p. 321].

"O... kay. Thanks for the heads-up». "No sweat», he smiled. "I warn everyone about her. She's so dangerous, I love her to death». "I hear you» [5, p. 348].

A communicative situation, when according to the English etiquette it is considered polite to thank someone, arises during greetings with friends, colleagues, acquaintances. That's why questions such as How are you? How are you doing/ getting on? How are things? will have similar answers: Fine, thanks; (I'm) very well, thank you; (I'm) Ok, thanks; Very well, thank you.

The research of American scientists M. Eisenstein and J. Bodman [4, p. 75] shows that, as a rule, having received a gift, one exclaims: "Oh how beautiful. How did you know? It's just what I wanted!» The authors note certain regularity, according to which the stronger feeling an individual is experiencing, the bigger is gratitude expressed. However, it should be mentioned, that the words used to convey gratitude depend on the particular person (person's inner world, well-being, emotional state, sex, age category, education etc.). For e.g.:

"See, that's all. I told you it wasn't much», I said. I hoped she wasn't disappointed in it. "It's beautiful, Landon», she said earnestly. "I'll wear it the next time I see you. Thank you» $[6, \mathrm{p} .41]$

"Well..." he murmured, lowering his eyes, and glancing at the watch I'd given him. "Thank you for the watch. I will always treasure it" [5, p. 195].

From these two reactions on the received gift, one can see that in the first example the answer is rather emotional and bright, while in the second one - more restrained.

Scientists M. Eisenstein and J. Bodman note that, with all the diversity of possible variants of expressing gratitude, there is a formed formula of gratitude verbalization in the minds of society [4, p. 77]. Therefore, expressing gratitude for received gift, most Americans emphasize the fact that there was no need to bring such a gift: "Oh you should not have» or «You did not have to».

Acknowledgement for the invitation can be expressed as a restrained thank you (example 1), or pour out in the flow of words of gratitude (2): 
1) «Thank you for coming over tonight», I said. She turned her attention back to me. "Thanks for inviting me» [6, p. 57].

2) "I thank you, ma'am, sincerely thank you»" said Marianne, with warmth: "your invitation has insured my gratitude for ever, and it would give me such happiness, yes, almost the greatest happiness I am capable of, to be able to accept it» "[8, p. 107].

An important feature of communicative behavior is that it is rarely confined to expressions with explicit gratitude in personal relationship. They are more often accompanied (or replaced) by emotional and evaluative phrases. This can be either an evaluation of an object of gratitude, an expression of attitude towards it, or evaluation of the interlocutor, his/her qualities or actions [9, p. 194-195]. Sometimes emotional expressions are more desirable, than a «dry» explicit appreciation, i.e., expressing an emotional evaluation is sometimes more appropriate than just saying «thank you».

"And you look very nice tonight in your tuxedo». He chuckled softly and Meredith tipped her head back, basking in the warmth of his smile as he said, "You look very nice too»"

[7, p. 21].

"It seems to me to recall that you hired a new manager for accessories, and he brought in a new buyer. Is that right?» «Perfectly correct, as always!» [7, p. 330]

The response to the words of gratitude can also be implicitly expressed. For e.g.:

«Thanks for the holiday, cuz». "Any time»», Farzad smiled [5, p. 150].

"Mister Vinson would like to thank you, Lightning-she, for your kind and compassionate understanding». "Always happy to help,» Dilip snarled [5, p. 241].

"Thanks, Vinson. You were at the service Karla organised. This is the first chance I've had to tell you, I appreciate it». "It was nothing. We were honored to attend, man" [5, p. 450].

"Thanks, Didier». "It is nothing». "No, I mean it. The owner of this building is your friend, and this is one of your areas, because local don is your friend, and that's why I'm safe here. Thanks, for everything» [5, p. 404].

«Thanks for your help». "Do not mention», he smiled. "May Jesus be with you, comrade». "And with you» [5, p. 355].

There are some units in the semantic field of gratitude that have moved from the sphere of compliment. These are phrases which emphasize the positive character of a person, who expresses gratitude.

The common features between gratitude and compliment are evident. Expressing gratitude, a person often combines it with a compliment, and vice versa. Therefore, these units should be considered with two illocutionary forces: compliment and gratitude.

1) «You have a wonderful laugh», he said quietly. "Thank you», she said, startled and pleased beyond proportion to the compliment [7, p. 55].

2) «And I just wanted to thank you for the volunteering as you did. You're a real gentleman» [6, p. 24].

3) «Why, thank you. You ... are a very agreeable young man» [5, p. 22].

There is a direct speech act in example 1 since the basic illocutionary purpose of gratitude is realized. The following examples 2, 3 have the purpose not to express gratitude, but compliment, since the basic illocutionary force in these examples is a compliment, and the secondary one - gratitude.

\section{Conclusions.}

1. The concept «gratitude» in English discourse has its own rules and norms, which sometimes differ from the Ukrainian ones.

2. The expressions of gratitude, which usually occur because of emotional and rational evaluation of what is happening, are highly stereotyped. Therefore, the main means of expressing gratitude in English is phrases Thanks/Thank you. However, depending on the communicative situation, the amplifying phrases such as a lot, very much, so, so much, really, thousand (thanks), from the bottom of my heart, etc are also used.

3. Gratitude can be addressed towards individuals, group of people and abstract notions in various communication situations. 
4. Gratitude may be expressed at the beginning of a conversation (etiquette gratitude); it also may be expressed for material (gift, money) or non-material (care, attention, support, help, affection, forewarning, compliment) service.

5. Appreciation may be expressed explicitly and implicitly. It is more appropriate to express acknowledgement implicitly in particular situations.

\title{
ЛІНГВОКОМУНІКАТИВНІ ОСОБЛИВОСТІ ВИСЛОВЛЮВАНЬ ПОДЯКИ АНГЛОМОВНОГО ДИСКУРСУ
}

\author{
А. Приходько, студентка \\ Сумський державний університет, \\ вул. Римського-Корсакова 2, Суми, Украӥна, \\ E-mail: Prykhodko56Annet@gmail.com
}

Робота виконана під керівництвом С. В. Баранової, канд. філол. наук, Сумський державний університет

Подана робота розглядає багатогранне явище подяки, якому притаманні дистинктивні риси у кожній мовній культурі, зокрема в англійській, а також аналізує особливості вираження вдячності в рамках англомовного художнього дискурсу. Особлива увага приділяється питанню детермінації дискурсу. У роботі використовується типологія дискурсу Г.Г. Почепџова, оскільки саме вона дає можливість провести аналіз висловлень подяки в рамках літературного дискурсу, який функціонує у просторі різнохарактерного контексту, формуючи при иџьому власний комунікативний простір.

Тематика роботи концентрується на лінгвокомунікативних особливостях висловлювань подяки, вербалізованих на сторінках англомовних художніх творів. Робота передбачає аналіз обставин висловлення вдячності, серед яких переважає необхідність дотриманням загальноприйнятих у суспільстві правил етики та є маркером вихованості та ввічливості людини. Розглядаються лексичні засоби номінації подяки та фактори, які впливають на спосіб ї̈ вербалізачії; зазначаються адресати подяки, серед яких конкретні особи та надприродні сили, а також вказуються мотиви висловлення вдячності, а саме : матеріальні чи нематеріальні блага.

У роботі наголошується на тому, шо подяка може у різних формах : як експлічитно, так імпліцитнн, щзо в деяких випадках, є навіть важливішим. Крім того, проводиться детальний розбір комунікативних ситуацій за яких прийнято складати подяку. У роботі зазначаються культурні аспекти вираження вдячності. Також звертається увага на прагматичні аспекти вживання висловлювань подяки, зокрема проводиться розмежування між вираженням компліменту та подяки за нього та подякоюкомпліментом, наводяться спільні та відмінні риси компліменту та подяки. Вказується, щчо вислови подяки можуть мати різну прагматику, яку необхідно вміти розпізнавати та враховувати задля уникнення непорозумінь під час спілкування.

Ключові слова: подяка, літературний дискурс, комунікативна ситуаџія, прагматичні аспекти

\section{ЛИНГВОКОММУНИКАТИВНЫЕ ОСОБЕННОСТИ ВЫРАЖЕНИЙ БЛАГОДАРНОСТИ АНГЛОЯЗЫЧНОГО ДИСКУРСА}

\author{
А. Приходько, студентка \\ Сумский государственный университет, \\ ул. Римского-Корсакова 2, Сумы, Украина, \\ E-mail: Prykhodko56Annet@gmail.com
}

Работа выполнена под руководством С. В. Барановой, канд. филол. наук,

Сумский государственный университет

Данная работа рассматривает многогранное явление благодарности, которому присущи дистинктивные черты в каждой языковой культуре, в частности в английской, а также анализирует особенности выражения благодарности в рамках англоязычного художественного дискурса. Тематика работы концентрируется на лингвокоммуникативных особенностях высказываний благодарности, вербализованных на странищах англоязычных художественных произведений. Работа предполагает анализ обстоятельств выражения благодарности, лексических средств номинации благодарности и факторов, влияющих на способ ее вербализации. Кроме того, проводится детальное рассмотрение коммуникативных ситуаций, в которых принято благодарить. В работе указываются культурные аспекты выражения благодарности. Также обращается внимание на прагматические аспекты употребления высказываний благодарности, в частности проводится разграничение между выражением комплимента и благодарности за него и благодарностью-комплиментом.

Ключевые слова: благодарность, литературный дискурс, коммуникативная ситуация, прагматические аспекть 


\section{REFERENCES}

1. Oxford English Dictionary (2012). [Electronic resource]. Oxford : Oxford University Press, 1024 p. - Access mode : https://en.oxforddictionaries.com/definition/gratitude. - (15.11.2017).

2. Vdyachnist. Wikipedia [Vikipedia. Vilna entsyklopedia.] - URL: https://uk.wikipedia.org/wiki/Вдячність (10.11.2017)

3. Larina T. V. (2003). The category of politeness in English and Russian communicative cultures. - Moscow : Izdatelstvo «RUDN», $315 \mathrm{~s}$.

4. Interlanguage pragmatics (1993). Ed. by Gabriele Kasper, Shoshana Blum-Kulka. New York : Oxford University Press, Inc, 252 p. - URL: https://books.google.com.ua/books?id=QAsbd2oi7LMC\&printsec $=$ frontcover $\& \mathrm{hl}=\mathrm{uk} \&$ source $=\mathrm{gbs} \_$atb\#v $=$onepage $\& \mathrm{q} \& \mathrm{f}=$ false. $-(20.11 .2017)$.

5. Roberts G. D. (2012). The Mountain Shadow. London : Little, Brown Book Group, 2012. 560 p.

6. Sparks N. (2013). A Walk to Remember. London : Little, Brown Book Group, 208 p.

7. McNaught, J. (1991). Paradise. New York : Eagle Syndication, Inc, 709 p.

8. Austen J. (2013). Sense and sensibility. London : Little, Brown Book Group, 208 p.

9. Karpchuk N. P. (2006). Addressing in official and non-official English discourse (communicative and pragmatic analysis) : monohraphiya. Lutsk : RVV «Vezha» Lesya Ukrainka Volynsk. state univ., $162 \mathrm{s.}$

\section{СПИСОК ВИКОРИСТАНИХ ДЖЕРЕЛ}

1. Oxford English Dictionary [Electronic resource]. — Oxford : Oxford University Press, 2012. - 1024 p. URL: https://en.oxforddictionaries.com/definition/gratitude. - (15.11.2017).

2. Вдячність [Електронний ресурс] // Вікіпедія. Вільна енциклопедія. - URL : https://uk.wikipedia.org/wiki/Вдячність. - (10.11.2017).

3. Ларина Т.В. Категория вежливости в английской и русской коммуникативных культурах / Т.В. Ларина. - М. : Изд-во РУДН, 2003. - 315 с.

4. Interlanguage pragmatics / ed. by Gabriele Kasper, Shoshana Blum-Kulka. - New York : Oxford University Press, Inc, 1993. - 252 p. - Access mode : https://books.google.com.ua/books?id=QAsbd2oi7LMC\&printsec= frontcover\&hl $=\mathrm{uk} \&$ source $=$ gbs_atb\#v=onepage \&q\&f=false. $-(20.11 .2017)$.

5. Roberts G.D. The Mountain Shadow / G.D. Roberts. - London : Little, Brown Book Group, 2012. - 560 p.

6. Sparks N. A Walk to Remember / N. Sparks. - London : Little, Brown Book Group, 2013. - 208 p.

7. McNaught J. Paradise / J. McNaught. - New York : Eagle Syndication, Inc, 1991. - 709 p.

8. Austen J. Sense and sensibility / J. Austen. - London : Little, Brown Book Group, 2013. - 208 p.

9. Карпчук Н. П. Адресованість в офіційному та неофіційному англомовному дискурсі (комунікативнопрагматичний аналіз) : монографія / Н. П. Карпчук. - Луцьк : РВВ «Вежа» Волин. держ. ун-ту ім. Лесі Українки, 2006. - 162 с.

Received: 20 Jenuary, 2018 